Article

\title{
New Insights towards High-Temperature Ethanol-Sensing Mechanism of ZnO-Based Chemiresistors
}

\author{
Lesia Piliai ${ }^{1}\left(0\right.$, David Tomeček ${ }^{2}$, Martin Hruška ${ }^{2}$, Ivan Khalakhan ${ }^{1}$, Jaroslava Nováková ${ }^{1}$,

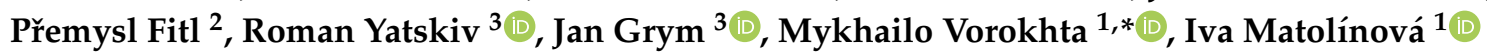 \\ and Martin Vrňata ${ }^{2, *}$ \\ 1 Department of Surface and Plasma Science, Faculty of Mathematics and Physics, Charles University, \\ V Holešovičkách 2, 18000 Prague 8, Czech Republic; lesiapiliai@gmail.com (L.P.); \\ ivan.khalakhan@mff.cuni.cz (I.K.); jaroslava.novakova@mff.cuni.cz (J.N.); \\ imatol@mbox.troja.mff.cuni.cz (I.M.) \\ 2 Department of Physics and Measurements, University of Chemistry and Technology Prague, Technická 5, \\ 16628 Prague 6, Czech Republic; david.tomecek@centrum.cz (D.T.); martin1.hruska@vscht.cz (M.H.); \\ premysl.fitl@vscht.cz (P.F.) \\ 3 Institute of Photonics and Electronics, Czech Academy of Sciences, Chaberská 1014/57, \\ 18251 Prague 8, Czech Republic; yatskiv@ufe.cz (R.Y.); grym@ufe.cz (J.G.) \\ * Correspondence: vorokhtm@mbox.troja.mff.cuni.cz (M.V.); martin.vrnata@vscht.cz (M.V.)
}

Received: 31 August 2020; Accepted: 23 September 2020; Published: 30 September 2020

\begin{abstract}
In this work, we investigate ethanol (EtOH)-sensing mechanisms of a $\mathrm{ZnO}$ nanorod (NRs)-based chemiresistor using a near-ambient-pressure X-ray photoelectron spectroscopy (NAP-XPS). First, the ZnO NRs-based sensor was constructed, showing good performance on interaction with $100 \mathrm{ppm}$ of EtOH in the ambient air at $327^{\circ} \mathrm{C}$. Then, the same $\mathrm{ZnO}$ NRs film was investigated by NAP-XPS in the presence of 1 mbar oxygen, simulating the ambient air atmosphere and $\mathrm{O}_{2} / \mathrm{EtOH}$ mixture at the same temperature. The partial pressure of $\mathrm{EtOH}$ was 0.1 mbar, which corresponded to the partial pressure of $100 \mathrm{ppm}$ of analytes in the ambient air. To better understand the EtOH-sensing mechanism, the NAP-XPS spectra were also studied on exposure to $\mathrm{O}_{2} / \mathrm{EtOH} / \mathrm{H}_{2} \mathrm{O}$ and $\mathrm{O}_{2} / \mathrm{MeCHO}(\mathrm{MeCHO}=$ acetaldehyde) mixtures. Our results revealed that the reaction of EtOH with chemisorbed oxygen on the surface of $\mathrm{ZnONRs}$ follows the acetaldehyde pathway. It was also demonstrated that, during the sensing process, the surface becomes contaminated by different products of $\mathrm{MeCHO}$ decomposition, which decreases dc-sensor performance. However, the ac performance does not seem to be affected by this phenomenon.
\end{abstract}

Keywords: near-ambient pressure XPS; ZnO nanorods; ethanol-sensing mechanism; acetaldehyde pathway; carbon contamination

\section{Introduction}

$\mathrm{ZnO}$ is an intrinsic n-type semiconductor with a wide band gap $\left(E_{g}=3.37 \mathrm{eV}\right)$ and an exciton binding energy of $60 \mathrm{meV}$ [1]. These properties, together with good chemical and thermal stability and low cost, make $\mathrm{ZnO}$ widely used in various fields and applications, including heterogeneous catalysis, photovoltaics and optoelectronics, and solar cells [2-4]. However, the most important application of $\mathrm{ZnO}$ is in chemiresistive gas sensors [5-8]. It was one of the first metal oxides reported as a promising material for the first gas sensor applications in the early 1960s [9]. Despite the fact that the ZnO-based gas sensors have been commercially used for the last three decades, the research on them is still far from being completed [10-12]. The research was particularly accelerated after the development 
of nanomaterials and nanotechnologies which demonstrated that the reduction in the grain size to nanometre dimensions significantly increases sensor sensitivity [13]. To date, the gas-sensing mechanism has not been fully explained. However, it is usually assumed that the change in sensor conductivity is connected with the chemisorption of atmospheric oxygen on the surface of the sensing layer [14]. Depending on the temperature, the oxygen extracts one or two free electrons from the surface, forming an electron depletion region there which reduces the total conductivity in the case of $\mathrm{n}$-type semiconductors and increases it for p-type ones. Exposing the sensor to a reducing analyte (like ethanol) lowers the concentration of chemisorbed oxygen species $\left(\mathrm{O}_{2}{ }^{-}, \mathrm{O}^{-}\right.$, and $\mathrm{O}^{2-}$ ) which return the electrons back to the surface and increase the conductivity [15]. In some cases, especially at a low temperature, the sensor conductivity may be related to the presence of molecular water or $\mathrm{OH}$ groups on the surface of the gas-sensitive material [16]. Sensor sensitivity is further related to many other parameters, including layer composition, morphology or the presence of dopants and catalysts. It has been demonstrated that nanostructuring can influence the thickness of the depleted region (Debye length), to be in tens of nanometers order for such metal oxides as $\mathrm{SnO}_{2}$ or $\mathrm{ZnO}$ [17].

A wide range of nanostructured $\mathrm{ZnO}$ films containing objects of different dimensions have been synthesized and tested as gas-sensing layers for gas sensors. Together with nanostructured $\mathrm{ZnO}$ films containing nanosized grains and nanocrystals, 1D and 2D nanostructured materials like nanorods (NRs), nanowires, nanosheets or nanobelts were reported to be effective for the detection of volatile organic compounds including ethanol ( $\mathrm{EtOH})$ and acetaldehyde (MeCHO). This broad topic is reviewed, e.g., in [18-20]. Partial studies dedicated to the detection of EtOH on $\mathrm{ZnO}$ NRs can be found in [21] or [22]. In the former case, the dc-response $S_{\mathrm{DC}}$ to $50 \mathrm{ppm}$ of EtOH was 22 at $320^{\circ} \mathrm{C}$. In the latter case, the dc-responce $S_{\mathrm{DC}}$ to $1000 \mathrm{ppm}$ of $\mathrm{EtOH}$ was 1.5 at $300^{\circ} \mathrm{C}$ (for the definition of $S_{\mathrm{DC}}$, see Section 2.4). It is apparent that these results are significantly different. The detection of $\mathrm{MeCHO}$ exclusively on $\mathrm{ZnO}$ NRs is reported only in [23]. The authors achieved $S_{\mathrm{DC}}=2.9$ to $10 \mathrm{ppm}$ of $\mathrm{MeCHO}$ at room temperature. Reports dedicated to the detection of $\mathrm{EtOH}$ or $\mathrm{MeCHO}$ on chemiresistors operating in ac-mode are rare. Certain conceptual approaches to the impedance measurement of sensors are discussed in [24]. In [25], the authors report the detection of ethanol vapours at a concentration of 0.7-5.0 ppm on $\mathrm{ZnO}$ nanorods at a working temperature of approximately $400{ }^{\circ} \mathrm{C}$. The nanorods were grown via a hydrothermal route directly on a multielectrode chip. By employing impedance measurements in tandem with signal processing by linear discriminant analysis, it is possible to distinguish vapours of various alcohols even in the sub-ppm range.

As mentioned above, the sensing mechanism of $\mathrm{EtOH}$ by $\mathrm{ZnO}$ remains partially unclear. One problem is that there are no direct experimental results evidencing the oxygen chemisorption in situ on the $\mathrm{ZnO}$ (or other metal oxide) surface at the sensor working conditions [26]. Furthermore, the ethanol reaction pathway with the oxygen species on the $\mathrm{ZnO}$ at the usual sensor working temperature of $300-400^{\circ} \mathrm{C}$ is frequently a matter of discussion. Based on the results from the reaction products' observation (by gas chromatography and temperature-programmed desorption techniques), two competitive pathways were proposed. The first one assumes the reaction of $\mathrm{EtOH}$ with chemisorbed oxygen producing $\mathrm{MeCHO}$ and water [10,27]:

$$
\begin{gathered}
\mathrm{EtOH}(\mathrm{ad})+\mathrm{O}^{-}(\mathrm{ad}) \rightarrow \mathrm{CH}_{3} \mathrm{CHO}+\mathrm{H}_{2} \mathrm{O}+\mathrm{e}^{-} \\
\mathrm{EtOH}(\mathrm{ad})+\mathrm{O}^{2-}(\mathrm{ad}) \rightarrow \mathrm{CH}_{3} \mathrm{CHO}+\mathrm{H}_{2} \mathrm{O}+2 \mathrm{e}^{-}
\end{gathered}
$$

The second pathway supposes $\mathrm{C}-\mathrm{O}$ bond scission leading to EtOH dehydration and ethylene formation, which then interacts with the oxygen ions, generating water and carbon dioxide [28,29]:

$$
\begin{gathered}
\mathrm{EtOH}(\mathrm{ad}) \rightarrow \mathrm{C}_{2} \mathrm{H}_{4}(\mathrm{ad})+\mathrm{H}_{2} \mathrm{O} \\
\mathrm{C}_{2} \mathrm{H}_{4}(\mathrm{ad})+3 \mathrm{O}_{2}{ }^{2-}(\mathrm{ad}) \rightarrow 2 \mathrm{CO}_{2}+2 \mathrm{H}_{2} \mathrm{O}+6 \mathrm{e}^{-}
\end{gathered}
$$


However, neither of these mechanisms account for the possible change in the sensing layer stoichiometry during interaction with $\mathrm{EtOH}$, or its deactivation by different strongly bonded carbonaceous species (coke, acetates) that may be formed as a result of the ethanol decomposition. Therefore, to resolve the mechanism, the utilization of an in situ/operando technique that provides information about and the sensing layer stoichiometry and various intermediate species on the surface under operational conditions is essential.

Near-ambient-pressure X-ray photoelectron Spectroscopy (NAP-XPS) is a technique that allows chemical investigation of solid surfaces in the presence of gases and vapours and provides important information on the reaction intermediate species appearing on the surface during different chemical reactions [30-32]. We recently utilized NAP-XPS for in situ investigation of the gas-sensing mechanism of nanostructured $\mathrm{SnO}_{2}$ - and $\mathrm{CuO}_{\mathrm{x}}$-based gas sensors [33,34]. In this work, we applied NAP-XPS for the investigation of the EtOH- and $\mathrm{MeCHO}$-sensing mechanisms of a $\mathrm{ZnO}$ NRs-based chemiresistor. First, sensing performance towards $100 \mathrm{ppm}$ of EtOH and $\mathrm{MeCHO}$ in the ambient air at $327^{\circ} \mathrm{C}$ was evaluated using a gas sensor with the $\mathrm{ZnO}$ NRs-sensing layer. Then, a $\mathrm{ZnO} \mathrm{NR}$ film on a silica substrate (fabricated in the same way) was investigated by NAP-XPS in various gas/vapour mixtures, simulating its normal operating conditions. The partial pressure of the analytes was $0.1 \mathrm{mbar}$, as it corresponds to the concentration of $100 \mathrm{ppm}$ under ambient pressure. To improve the understanding of the mechanism, the influence of water vapour was also investigated.

\section{Materials and Methods}

\subsection{Synthesis of $\mathrm{ZnO} N$ Rs and Fabrication of Sensors}

The $\mathrm{ZnO}$ NRs were grown on seeding layers by chemical bath deposition (CBD) from equimolar aqueous solutions consisting of $50 \mathrm{mM}$ zinc nitrate hexahydrate and hexamethylentetramine at $95{ }^{\circ} \mathrm{C}$ for $2 \mathrm{~h}$ [35]. The NRs were prepared on a silicon substrate for the NAP-XPS measurements, while for the investigation of the sensing properties, alumina substrates with Pt electrodes were used (Figure 1). The seed layer was deposited by pulsed laser deposition. Deposition was carried out by a laser Quantel Brilliant (wavelenght $266 \mathrm{~nm}$, pulse duration $4 \mathrm{~ns}$, repetition rate $10 \mathrm{~Hz}$ ). The energy of laser pulses was $45 \mathrm{~mJ}$. The target was made from $\mathrm{ZnO}$ with $5 \mathrm{~N}$ purity (pressed and then sintered in a furnace). The system was evacuated to high vacuum conditions and the deposition was carried out in $20 \mathrm{~Pa}$ of oxygen at room temperature. The target substrate distance was $5 \mathrm{~cm}$. The total number of laser pulses was 300. The AFM image of the seed layer on the silicon substrate is presented in Figure S1 of the Supporting Information.

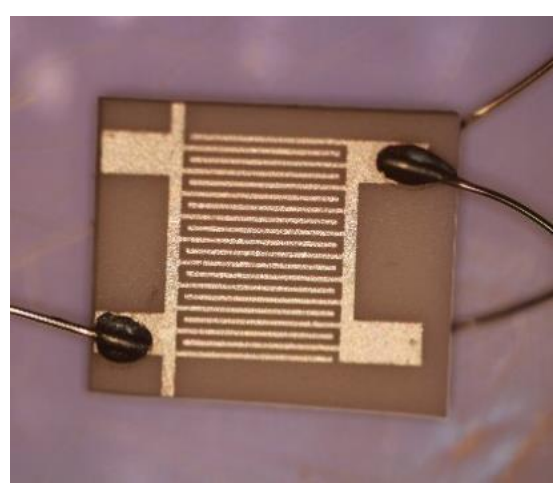

(a)

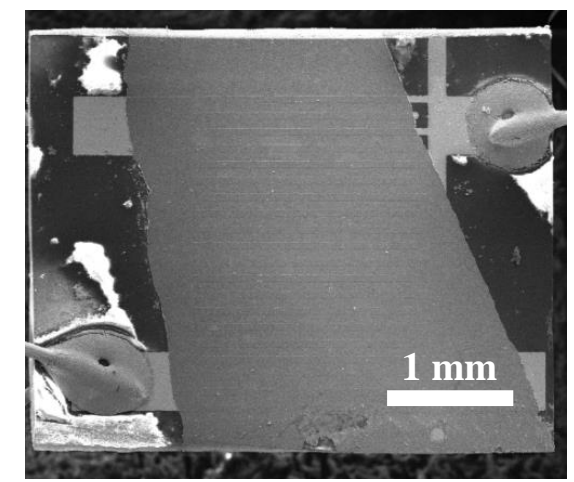

(b)

Figure 1. Optical microscope image of the alumina-sensing platform with Pt electrodes (a) and SEM image of the $\mathrm{ZnO}$ NRs prepared on it (b). 


\subsection{Morphological and Structural Characterizations}

The morphology and structure of the $\mathrm{ZnO}$ NRs were examined by scanning electron microscopy (SEM) using a Tescan MIRA 3 microscope operating at $30 \mathrm{keV}$ electron beam energy and by high-resolution transmission microscopy (HRTEM) using a $200 \mathrm{kV} J E O L$ 2100FEG UHR microscope with a Scherzer resolution of $0.19 \mathrm{~nm}$. The TEM images were recorded by a charge-coupled device camera and analyses of the results were performed using the Digital Micro-graph software.

\subsection{In Situ NAP-XPS Characterizations}

The NAP-XPS measurements were performed using a lab-based NAP-XPS system (SPECS Surface Nano Analysis, GmbH Germany) equipped with the monochromatized Al K $\alpha$ X-ray source, hemispherical electron energy analyser and specially designed NAP cell. A detailed description of this system can be found in [33]. Investigations into the sensor interaction with a low concentration of ethanol were performed as follows: first, the XPS spectra were acquired at $327^{\circ} \mathrm{C}$ in 1 mbar of oxygen, mimicking the ambient atmosphere without a reducing agent; then, the same sets of spectra were measured in the $\mathrm{O}_{2} / \mathrm{EtOH}$ mixture, prepared by increasing the total gas pressure in the NAP cell to $1.1 \mathrm{mbar}$ by adding ethanol vapour. The $\mathrm{O}_{2} / \mathrm{EtOH} / \mathrm{H}_{2} \mathrm{O}$ mixture was created by adding $0.1 \mathrm{mbar}$ of water vapour to the $\mathrm{EtOH} / \mathrm{O}_{2}$ mixture. Finally, the same set of spectra was measured in the presence of the $\mathrm{O}_{2} / \mathrm{MeCHO}$ atmosphere prepared inside the NAP cell in a similar way (by the increase in the total gas pressure to 1.1 mbar and by the addition of 0.1 mbar of acetaldehyde vapour). During all NAP-XPS measurements, the $\mathrm{Zn} 2 \mathrm{p}, \mathrm{Zn} \mathrm{LMM}, \mathrm{O} 1 \mathrm{~s}$ and $\mathrm{C} 1 \mathrm{~s}$ spectra were recorded at a constant pass energy of $20 \mathrm{eV}$ and a photoelectron emission angle of $0^{\circ}$, with respect to the sample normal. The spectral components in the core-level spectra were fitted with a Voigt profile after subtracting the Shirley background using the KolXPD-fitting software.

\subsection{Instrumentation and Evaluation of Sensor Measurement in Dc- and Ac-Mode}

DC measurements were conducted with an Agilent $34410 A$ in a sensor evaluation system described in [36]. The AC ones (impedance measurements) were performed with an Agilent 4294A impedance analyzer in a system depicted in Figure S2 of SI. The impedance measurements were carried out in two-wire connection in the frequency range of $40 \mathrm{~Hz}-100 \mathrm{MHz}$ (at 800 frequency points in logarithmic scale). The amplitude of a testing signal was set to $10 \mathrm{mV}$ with no bias voltage. Both $\mathrm{DC}$ and $\mathrm{AC}$ measurements were done for four distinct analyte mixtures $\left(\mathrm{EtOH} ; \mathrm{MeCHO}\right.$; $\mathrm{EtOH}+\mathrm{H}_{2} \mathrm{O}$; $\mathrm{MeCHO}+\mathrm{H}_{2} \mathrm{O}$ ) with the concentration of $100 \mathrm{ppm}$ for each component (the rest of the mixture was synthetic air at 1 bar pressure). The gas flow was set to $25 \mathrm{~mL} / \mathrm{min}$ and sensor temperature to $327^{\circ} \mathrm{C}$. The block diagram of the station for measuring the chemiresistor response in the DC and AC modes is presented in Figure 2.

First, the sensors were stabilized at their operating temperature for $2 \mathrm{~h}$. Then, they were alternately exposed to analyte and reference mixtures at 1 bar pressure. The reference mixture was pure synthetic air without any analyte. The exposure to analyte mixtures lasted $10 \mathrm{~min}$. The exposure to the reference mixture took 30-60 min depending on the speed of sensor recovery.

Sensor responses were evaluated using the following quantities: $S_{\mathrm{DC}}, S_{\mathrm{AC} 40 \mathrm{~Hz}}$ and $S_{\mathrm{PA}-\mathrm{MAX}}$. $S_{\mathrm{DC}}$ was defined as a ratio of corresponding pre-exposure and post-exposure resistances $\left(S_{\mathrm{DC}}=R_{\mathrm{air}} / R_{\text {analyte }}\right)$. The impedance data were processed as follows: (i) Nyquist plots (i.e., imaginary part of complex impedance $\operatorname{Im}(Z)$ vs. real part complex impedance $\operatorname{Re}(Z)$ with the frequency of measuring signal as a parameter) were constructed. (ii) The phase angles $\Theta$ of complex impedance of the sensor in "pure" synthetic air $\left(\Theta_{\text {air }}=\arccos \left[\operatorname{Re}\left(Z_{\text {air }}\right) /\left|Z_{\text {air }}\right|\right]\right)$ and complex impedance of the same sensor in analyte $\left(\Theta_{\text {analyte }}=\arccos \left[\operatorname{Re}\left(Z_{\text {analyte }}\right) /\left|Z_{\text {analyte }}\right|\right]\right)$ were calculated. The symbol $|Z|$ denotes impedance modulus, which means $|Z|=\left[\operatorname{Re}^{2}(Z)+\operatorname{Im}^{2}(Z)\right]^{1 / 2}$. (iii) Phase-angle sensitivity $S_{P A}$ was defined as a difference in the phase angles in synthetic air and in analyte, respectively, i.e., $S_{P A}=\Theta_{\text {air }}-\Theta_{\text {analyte }}$. It is clear that $Z, \Theta$ and $S_{\mathrm{PA}}$ are frequency-dependent quantities. (iv) The parameter $S_{\mathrm{PA}-\mathrm{MAX}}$ is the 
maximum value of $S_{\mathrm{PA}}$ achieved for a sensor. (v) The parameter $S_{\mathrm{AC} 40 \mathrm{~Hz}}$ is a ratio of the real parts of the corresponding impedances in air and in analyte at $40 \mathrm{~Hz}$, i.e., $S_{\mathrm{AC} 40 \mathrm{~Hz}}=\operatorname{Re}\left(Z_{\text {air }}\right) / \operatorname{Re}\left(Z_{\text {analyte }}\right)$. Further information concerning AC measurements is available in $[37,38]$.

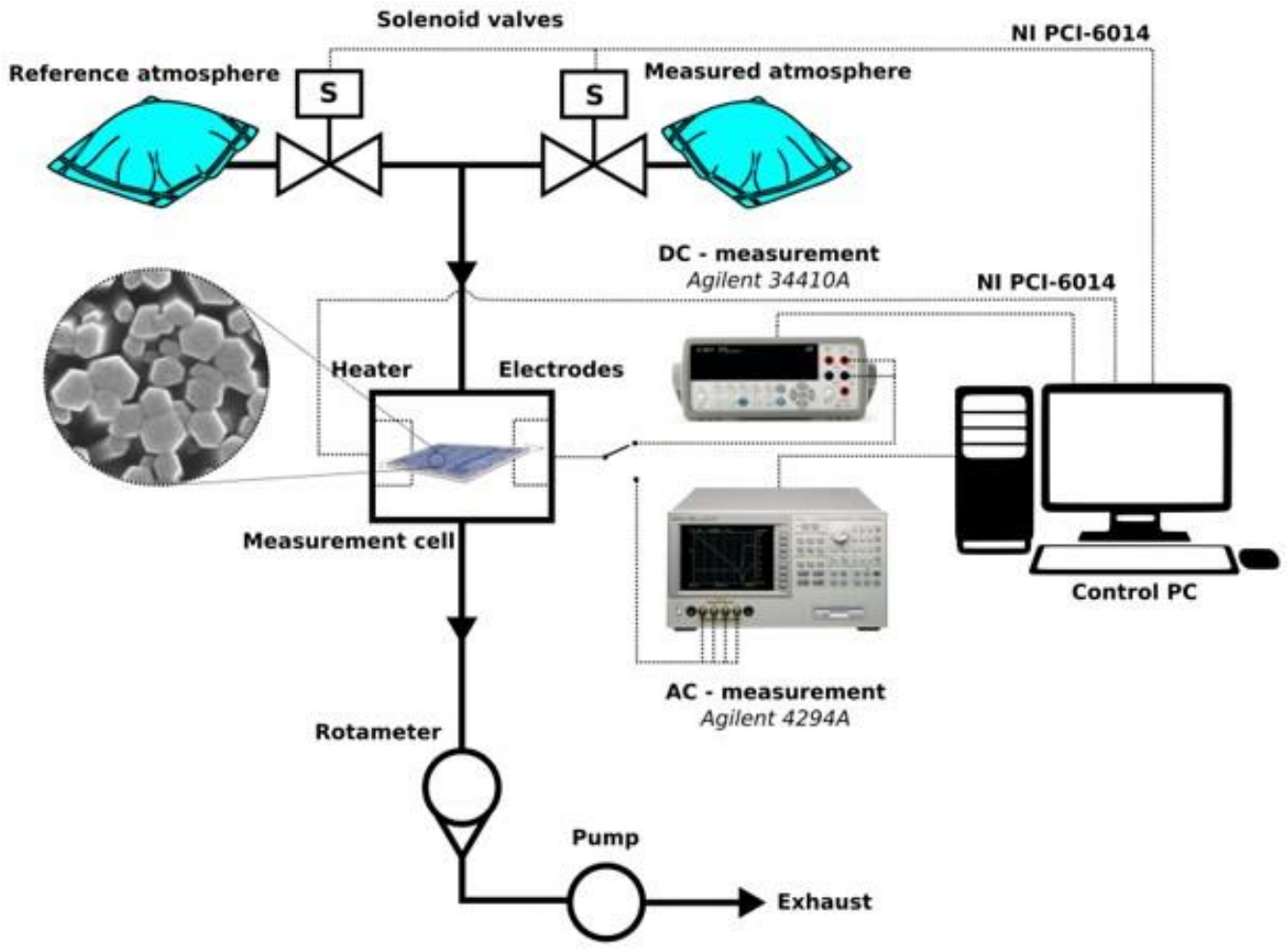

Figure 2. Block diagram of the station for measuring the chemiresistor response.

\section{Results and Discussion}

\subsection{Structural and Morphological Analysis}

Figure 3a presents the SEM micrograph of the ZnO NRs grown on the silicon substrate for the NAP-XPS measurements. The image shows a compact array of vertically aligned, single-crystalline $\mathrm{ZnO}$ NRs with a diameter varying within the 50-150 $\mathrm{nm}$ range. The TEM image of the top part of a single $\mathrm{ZnO} \mathrm{NR}$ is presented in Figure $3 \mathrm{~b}$. It confirms the crystallinity of ZnO NRs with a hexagonal wurtzite structure. The NRs prepared on the alumina sensor substrates for investigation of the EtOH-sensing properties (depicted in Figure 3c) had the same size, but more random orientation due to the greater substrate roughness.
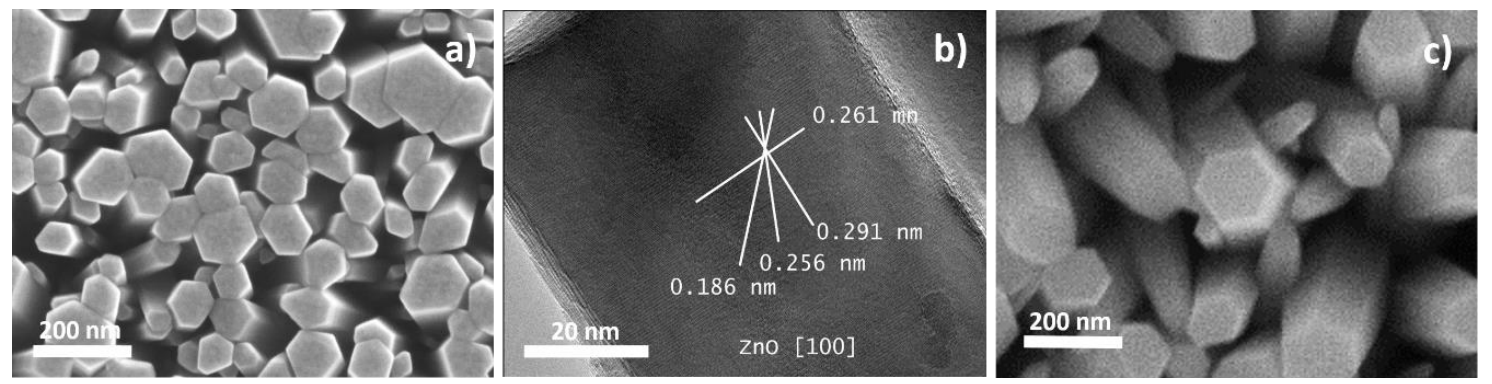

Figure 3. SEM (a) and TEM (b) images of the ZnO NRs grown on the silicon substrate and (c) SEM image of the $\mathrm{ZnO}$ NRs prepared on the sensing platform. 


\subsection{NAP-XPS Analysis}

The XPS measurements of the as-prepared ZnO NRs done in the presence of 1 mbar of oxygen at room temperature showed a relatively high amount of carbon contamination on the surface (Figure 4). After heating the sample to a sensor working temperature of $327^{\circ} \mathrm{C}$ in 5 mbar of oxygen, the amount of surface carbon decreased by only about $30 \%$. Thus, prior to the measurements, a special sample cleaning protocol was applied, which included the sample annealing at $500{ }^{\circ} \mathrm{C}$ for about $60 \mathrm{~min}$ in 5 mbar of $\mathrm{O}_{2}$ with a further decrease in the oxygen pressure and sample temperature to 1 mbar and $327^{\circ} \mathrm{C}$, respectively. After this, the carbon contamination decreased to about $5 \%$ of the initial amount and the sensor was considered to be cleaned. However, this indicates that the carbon contamination must also be present on the surface of a real working sensor and should be taken into account when considering the sensing mechanism and sensor performance. The cleaned sensor was then exposed to the $\mathrm{O}_{2} / \mathrm{EtOH}, \mathrm{O}_{2} / \mathrm{EtOH} / \mathrm{H}_{2} \mathrm{O}$ and $\mathrm{O}_{2} / \mathrm{MeCHO}$ gas atmospheres at $327^{\circ} \mathrm{C}$ in order to understand the processes taking place on the surface of the $\mathrm{ZnO}$ NRs-based sensor while sensing $\mathrm{EtOH}$ or $\mathrm{MeCHO}$ molecules. Before each exposure, the sample was also cleaned, but it was enough to anneal it at only $327^{\circ} \mathrm{C}$ in the presence of $5 \mathrm{mbar} \mathrm{O}_{2}$ to remove all carbon.

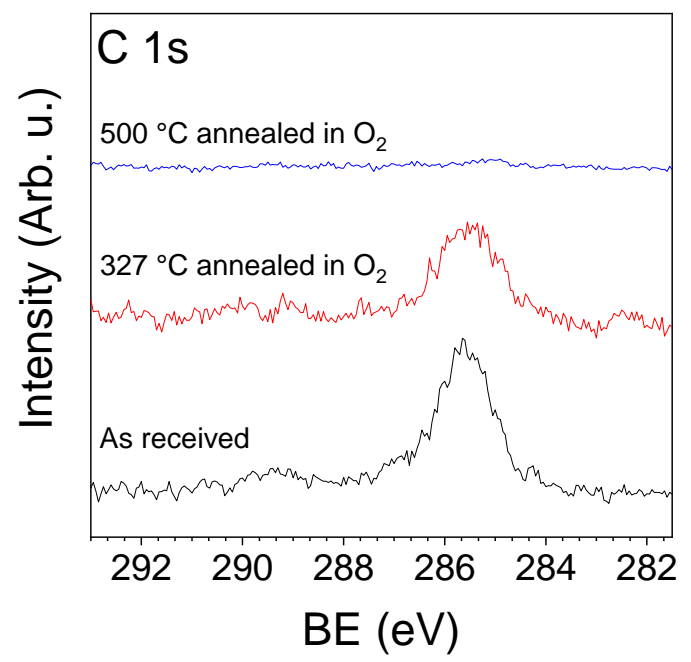

Figure 4. NAP-XPS spectra of the $\mathrm{C} 1 \mathrm{~s}$ core-level acquired from the as-received $\mathrm{ZnO}$ NRs, after annealing in $5 \mathrm{mbar} \mathrm{O}_{2}$ at $327^{\circ} \mathrm{C}$ and after annealing in $5 \mathrm{mbar} \mathrm{O}_{2}$ at $500{ }^{\circ} \mathrm{C}$.

The $\mathrm{C}$ 1s spectra measured in the presence of $\mathrm{O}_{2}, \mathrm{O}_{2} / \mathrm{EtOH}, \mathrm{O}_{2} / \mathrm{EtOH} / \mathrm{H}_{2} \mathrm{O}$ and $\mathrm{O}_{2} / \mathrm{MeCHO}$ are presented in Figure 5. The $\mathrm{C}$ 1s spectrum acquired from the cleaned $\mathrm{ZnO}$ NRs in the presence of oxygen (the bottom spectrum) showed some small amount of carbon contamination, with the main peak at about $285.2 \mathrm{eV}$ (black peak). This peak can be assigned to amorphous carbon and different $\mathrm{CH}_{\mathrm{x}}$ species adsorbed on the surface of $\mathrm{ZnO}$ [39]. The two peaks at 286.5 and $289.4 \mathrm{eV}$ (pink color peaks) most probably belong to the methyl and carboxylate groups of surface acetates [40], which appeared on the surface during NRs synthesis. The peak at $289.4 \mathrm{eV}$ could also originate from carbonates that may be formed after high-temperature annealing of the contaminated $\mathrm{ZnO}$ surface in oxygen. Sample exposure to the $\mathrm{O}_{2} / \mathrm{EtOH}$ mixture led to significant changes in the $\mathrm{C}$ 1s spectrum (second spectrum from the bottom in Figure 5). The peaks assigned to the surface acetates doubled, and position of the methyl peak shifted to a lower binding energy (BE) by $0.3 \mathrm{eV}$. The peak assigned to amorphous carbon and $\mathrm{CH}_{\mathrm{x}}$ groups at $285.2 \mathrm{eV}$ also increased. In addition, two equal peaks at about 285.6 and $287 \mathrm{eV}$ (blue peaks), assigned to the methyl and alxoxy groups of ethoxy (the intermediate product of ethanol dehydrogenation), respectively, and two small peaks at about 287.6 and $286.1 \mathrm{eV}$ of gas phase EtOH (green peaks) appeared in the spectrum. The intensity and shape of the $\mathrm{EtOH}$ gas peaks, as well as the distance between them, were determined on the basis of a reference measurement of an $\mathrm{O}_{2} / \mathrm{EtOH}$ mixture with no sample inside the NAP cell (see Figure S3 of SI). It is worth noting that the increase 
in the peaks' intensity at 289.4 and $286.5 \mathrm{eV}$, together with the shift of the last by $0.3 \mathrm{eV}$ to lower BE (from $286.5 \mathrm{eV}$ to $286.2 \mathrm{eV}$ ), is most probably related to the presence of $\mathrm{MeCHO}$ on the surface. Indeed, $\mathrm{MeCHO}$ contains a formyl (aldehyde) group with a double $\mathrm{C}=\mathrm{O}$ bond, giving rise to an XPS peak at about 289-290 eV and a methyl group producing an XPS peak at a slightly lower BE of 285-286 eV compared to the surface acetates [41]. Adding water to the $\mathrm{O}_{2} / \mathrm{EtOH}$ mixture (second spectrum from the top in Figure 5), resulted in a slight increase in the $\mathrm{MeCHO}$ signals and a decrease in the ethoxy and amorphous carbon peaks. The $\mathrm{C} 1$ s spectrum measured in the presence of the $\mathrm{O}_{2} / \mathrm{MeCHO}$ mixture (the top spectrum in Figure 5) consisted of the already-observed peaks of adsorbed $\mathrm{MeCHO}$ and amorphous carbon, and two new peaks at about 289 and $286.4 \mathrm{eV}$ (dark blue), which are the formyl and methyl features of gas-phase $\mathrm{MeCHO}$. The intensity and shape of these gas-phase peaks, as well as the distance between them, were found from the reference NAP-XPS measurement of $\mathrm{O}_{2} / \mathrm{MeCHO}$ gas mixture (Figure S3 of SI).

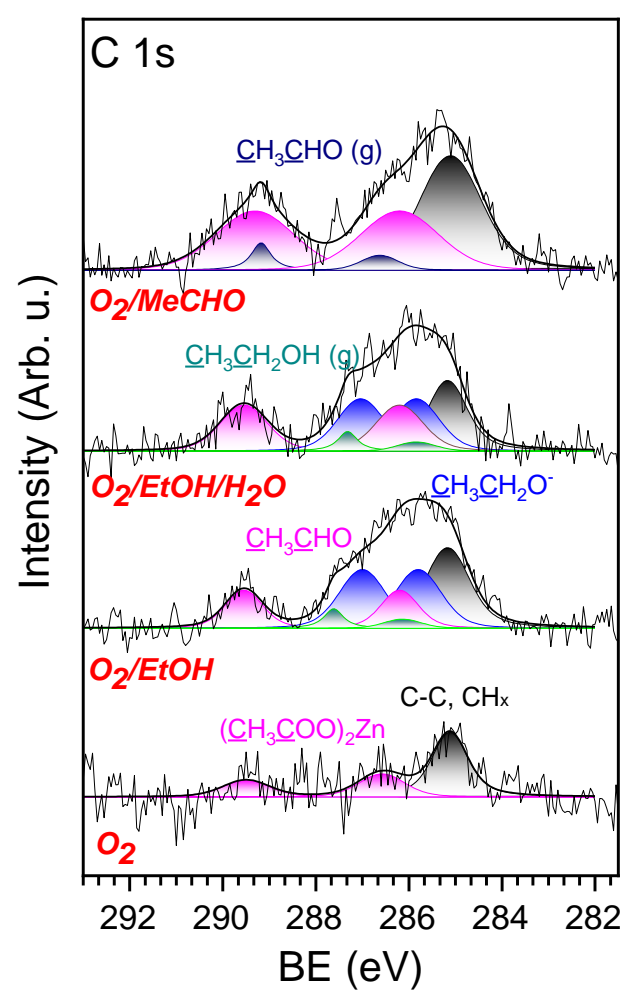

Figure 5. NAP-XPS spectra of the $\mathrm{C} 1$ s core-level acquired on the $\mathrm{ZnO}$ NRs-based sensor in the presence of $\mathrm{O}_{2}, \mathrm{O}_{2} / \mathrm{EtOH}, \mathrm{O}_{2} / \mathrm{EtOH} / \mathrm{H}_{2} \mathrm{O}$ and $\mathrm{O}_{2} / \mathrm{MeCHO}$ at $327^{\circ} \mathrm{C}$.

The corresponding $\mathrm{O} 1 \mathrm{~s}, \mathrm{Zn} 2 \mathrm{p}$ and $\mathrm{Zn}$ LMM spectra acquired in the presence of $\mathrm{O}_{2}, \mathrm{O}_{2} / \mathrm{EtOH}$, $\mathrm{O}_{2} / \mathrm{EtOH} / \mathrm{H}_{2} \mathrm{O}$ and $\mathrm{O}_{2} / \mathrm{MeCHO}$ are presented in Figure 6 and Figure $\mathrm{S} 4$ of SI. The O 1s spectra showed slight changes depending on the exposing atmosphere. This is mainly because of the strong oxygen signal originating from bulk $\mathrm{ZnO}$, with the main state at about $531 \mathrm{eV}$. This peak is so intense that the low oxygen signal originating from the adsorbate is almost undetectable by XPS. The inset in Figure 6a, demonstrating the difference between $\mathrm{O} 1$ s spectra taken in $\mathrm{O}_{2}$ and $\mathrm{O}_{2} / \mathrm{EtOH}$ atmospheres, shows an increase in oxygen signal in the $531.5-533 \mathrm{eV}$ region. In this region, the oxygen signals from different hydrocarbons containing oxygen, $\mathrm{H}_{2} \mathrm{O}$ and $\mathrm{OH}$ usually appear [42]. Similar signal increases can be observed in the case of $\mathrm{O}_{2} / \mathrm{EtOH} / \mathrm{H}_{2} \mathrm{O}$ and $\mathrm{O}_{2} / \mathrm{MeCHO}$ atmospheres. However, these contributions are so small that it is impossible to make any quantitative analysis or to fit them. Compared to the oxygen spectra, the corresponding $\mathrm{Zn} 2 \mathrm{p}$ spectra contained even smaller changes (Figure 6b). In all cases, there was a doublet, with the position of the main peak at about $1022 \mathrm{eV}$ corresponding to the $\mathrm{Zn}^{2+}$ ions of bulk $\mathrm{ZnO}$ [43]. Comparison of the spectra after their normalization to the same height did not show any difference in their shape, except for a shift of about $0.15 \mathrm{eV}$ to 
higher binding energy for the spectrum acquired in the pure oxygen atmosphere. As this shift was noticed for the whole set of spectra ( $\mathrm{Zn} \mathrm{2p,} \mathrm{Zn} \mathrm{LMM,} \mathrm{O} \mathrm{1s} \mathrm{and} \mathrm{C} \mathrm{1s} \mathrm{spectra)} \mathrm{collected} \mathrm{in} \mathrm{oxygen,}$ we attributed it to the band-bending effect raised by oxygen chemisorption that occurs at $327^{\circ} \mathrm{C}$ [44]. For easier comparison, the effect of band bending was eliminated by shifting the whole set of spectra measured in oxygen by $0.15 \mathrm{eV}$ to a higher BE prior to the spectra processing. The Zn LMM Auger spectra were acquired together with the Zn 2p spectra and presented in Figure S4 of SI. These spectra resembled typical Auger spectra of $\mathrm{ZnO}$ with the main peak at about $988 \mathrm{eV}$ [43], regardless of the exposing atmosphere.
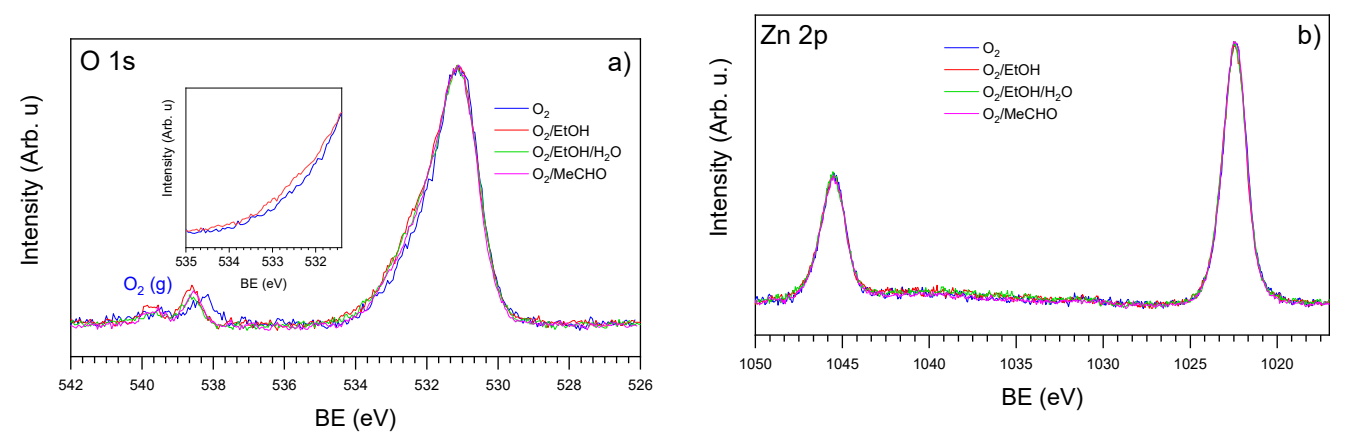

Figure 6. NAP-XPS spectra of $\mathrm{O} 1 \mathrm{~s}(\mathbf{a})$ and $\mathrm{Zn} 2 \mathrm{p}(\mathbf{b})$ acquired from the $\mathrm{ZnO}$ NRs-based sensor in the presence of $\mathrm{O}_{2}, \mathrm{O}_{2} / \mathrm{EtOH}, \mathrm{O}_{2} / \mathrm{EtOH} / \mathrm{H}_{2} \mathrm{O}$ and $\mathrm{O}_{2} / \mathrm{MeCHO}$ at $327^{\circ} \mathrm{C}$.

The NAP-XPS results presented above supported the theory of an $\mathrm{MeCHO}$ reaction pathway for the $\mathrm{EtOH}$ reaction with the chemisorbed oxygen species described in the introduction. We could not detect any signal related to ethylene with a double $\mathrm{C}=\mathrm{C}$ bond usually appearing at 284-284.2 eV [45], which rules out the ethylene pathway at this temperature. It is apparent that the EtOH gas-sensing mechanism includes the formation of the ethoxy group that is an intermediate product of $\mathrm{MeCHO}$ formation via two-step EtOH dehydrogenation. (The process includes an $\mathrm{O}-\mathrm{H}$ bond scission forming the ethoxy group in the first step. The second hydrogen detaches in the second step, and the carbon skeleton forms $\mathrm{MeCHO}$ ). The detached hydrogens interact with the chemisorbed oxygen species, forming $\mathrm{H}_{2} \mathrm{O}$. However, the more intense peak in amorphous carbon at $285.2 \mathrm{eV}$ in case of the $\mathrm{O}_{2} / \mathrm{MeCHO}$ measurements points to further decomposition of the MeCHO molecules that, in turn, could decrease sensor performance. This may explain the lower response of the $\mathrm{ZnO}$ sensor to $\mathrm{MeCHO}$, as discussed in the next section. Moreover, it looks as if water on the surface of ZnO NRs partially blocks the $\mathrm{MeCHO}$ decomposition, leading to the increase in its concentration on the surface and a slight decrease in amorphous carbon formed as a result of $\mathrm{MeCHO}$ decomposition. However, as shown below, this has a very low influence on sensor performance.

\subsection{Response of Sensor in Dc-and Ac-Modes}

To investigate the sensing properties of $\mathrm{ZnO}$-nanorods in macroscale, the prepared sensor devices (chemiresistors) were measured in both dc- and in ac-mode. Figure 7 depicts a dc-response to $\mathrm{EtOH}$ and $\mathrm{EtOH} / \mathrm{H}_{2} \mathrm{O}$, while Figure 8 depicts the dc-response to $\mathrm{MeCHO}$ and $\mathrm{MeCHO} / \mathrm{H}_{2} \mathrm{O}$. Figures 9 and 10 present certain results extracted from ac-responses, i.e., the dependence of phase-angle responses on the frequency of a measuring signal for $\mathrm{EtOH}$ and $\mathrm{EtOH} / \mathrm{H}_{2} \mathrm{O}$ (Figure 9) or $\mathrm{MeCHO}$ and $\mathrm{MeCHO} / \mathrm{H}_{2} \mathrm{O}$ (Figure 10). Table 1 summarizes the important sensor parameters evaluated from Figures 6-10, namely, dc-responses, ac-responses at $40 \mathrm{~Hz}$ and maximum phase-angle responses $S_{\text {PA-MAX }}$. Both instrumentation of the measurement and sensor parameters evaluation were carried out according to the procedures described in the experimental part.

In the following text, sensor responses are analyzed first, and, secondly, they are correlated with the phenomena revealed by the NAP-XPS spectroscopy of corresponding systems. Analysis of the sensor responses resulted in the following observations: 
(i) $\mathrm{ZnO}$ behaves like an n-type semiconductor-both reducing analytes (EtOH and $\mathrm{MeCHO})$ decrease either its resistance or its impedance modulus (see Figures 7 and 8);

(ii) The responses to $\mathrm{EtOH}$ and $\mathrm{EtOH} / \mathrm{H}_{2} \mathrm{O}$ are more stable than the responses to $\mathrm{MeCHO}$ and $\mathrm{MeCHO} / \mathrm{H}_{2} \mathrm{O}$. This is especially apparent when comparing the stability of the sensor baseline during the dc-measurement (cf. Figures 7 and 8). Within the ac-measurements, this fact is manifested by a significant drift in $S_{\mathrm{PA}}$ in time for $\mathrm{MeCHO}$ (cf. Figures 9 and 10);

(iii) While the $S_{\mathrm{DC}}$ values are higher for $\mathrm{EtOH}$ and $\mathrm{EtOH} / \mathrm{H}_{2} \mathrm{O}, S_{A C 40 \mathrm{~Hz}}$ and $S_{\mathrm{PA}-\mathrm{MAX}}$ are greater for $\mathrm{MeCHO}$ and $\mathrm{MeCHO} / \mathrm{H}_{2} \mathrm{O}$, i.e., $\mathrm{EtOH}$ is easily detectable by a dc-measurement and $\mathrm{MeCHO}$ by an ac-measurement;

(iv) The effect of water on chemiresistor responses is relatively weak at $327^{\circ} \mathrm{C}$;

(v) The magnitude of the dc-response is somewhat decreased in each subsequent step (see Figures 7 and 8).

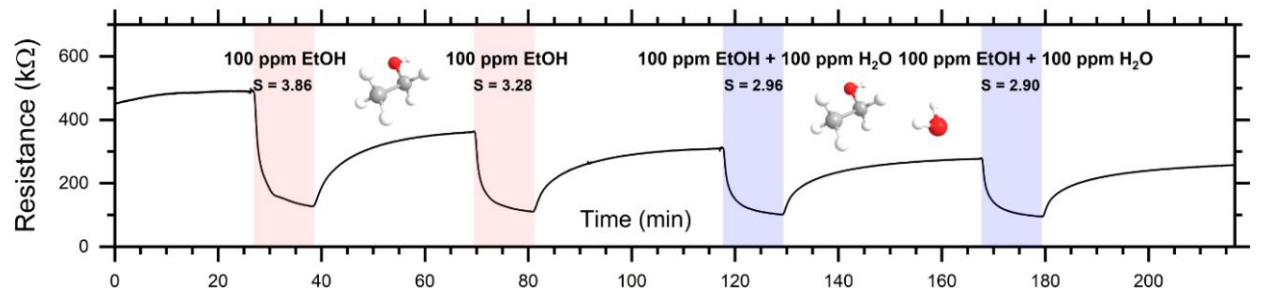

Figure 7. Responses of the $\mathrm{ZnO}$-nanorod-based chemiresistor to $\mathrm{EtOH}$ and $\mathrm{EtOH} / \mathrm{H}_{2} \mathrm{O}$ vapours. The sequence of atmospheres was as follows: reference air $\rightarrow 100 \mathrm{ppm} \mathrm{EtOH} \rightarrow$ reference air $\rightarrow 100 \mathrm{ppm}$ $\mathrm{EtOH} \rightarrow$ reference air $\rightarrow 100 \mathrm{ppm} \mathrm{EtOH}+100 \mathrm{ppm} \mathrm{H}_{2} \mathrm{O} \rightarrow$ reference air $\rightarrow 100 \mathrm{ppm} \mathrm{EtOH}+100 \mathrm{ppm}$ $\mathrm{H}_{2} \mathrm{O} \rightarrow$ reference air.

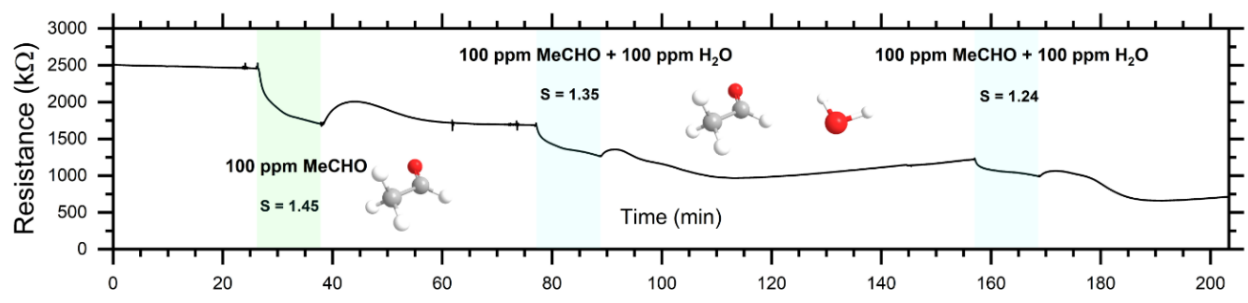

Figure 8. Responses of the $\mathrm{ZnO}$-nanorods based chemiresistor to $\mathrm{MeCHO}$ and $\mathrm{MeCHO} / \mathrm{H}_{2} \mathrm{O}$ vapours. The sequence of atmospheres was: reference air $\rightarrow 100 \mathrm{ppm} \mathrm{MeCHO} \rightarrow$ reference air $\rightarrow 100 \mathrm{ppm}$ $\mathrm{MeCHO}+100 \mathrm{ppm} \mathrm{H}_{2} \mathrm{O} \rightarrow$ reference air $\rightarrow 100 \mathrm{ppm} \mathrm{MeCHO}+100$ ppm $\mathrm{H}_{2} \mathrm{O} \rightarrow$ reference air.

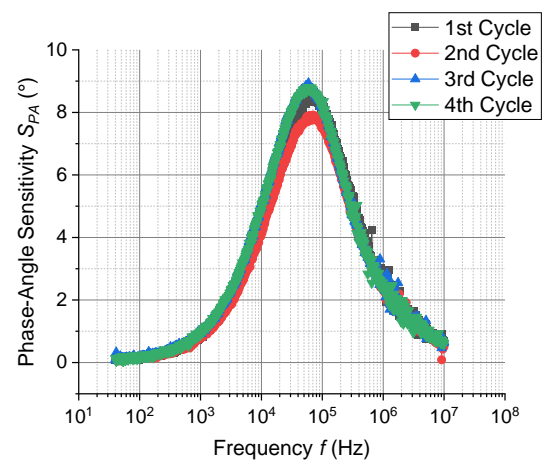

(a)

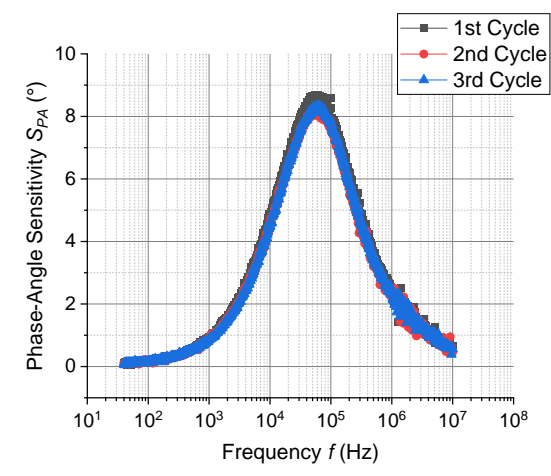

(b)

Figure 9. The dependence of phase-angle response vs. frequency for $100 \mathrm{ppm} \mathrm{EtOH} \mathrm{(a);} 100 \mathrm{ppm}$ $\mathrm{EtOH}+100$ ppm $\mathrm{H}_{2} \mathrm{O}(\mathbf{b})$. The reference atmosphere was synthetic air. 


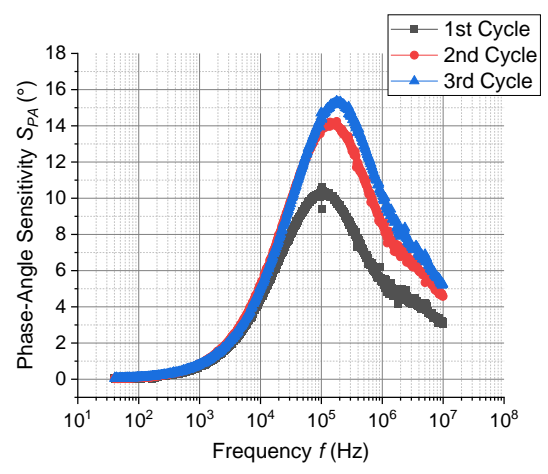

(a)

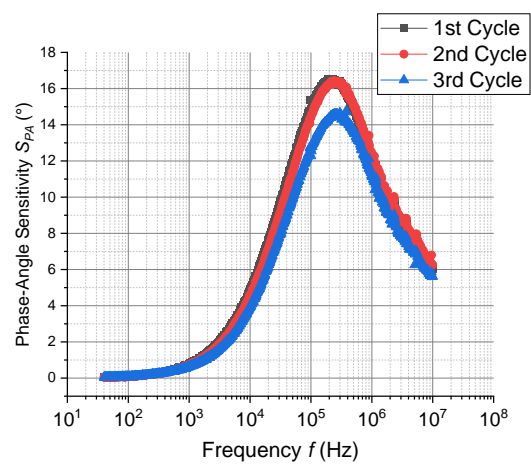

(b)

Figure 10. The dependence of phase-angle response vs. frequency for $100 \mathrm{ppm} \mathrm{MeCHO} \mathrm{(a);} 100 \mathrm{ppm}$ $\mathrm{MeCHO}+100$ ppm $\mathrm{H}_{2} \mathrm{O}(\mathbf{b})$. The reference atmosphere was synthetic air.

Table 1. Detection parameters of $\mathrm{ZnO}$-nanorod based chemiresistors: dc-response $\left(S_{\mathrm{DC}}\right)$; ac-response at $40 \mathrm{~Hz}\left(S_{A C 40 \mathrm{~Hz}}\right)$; maximum phase-angle response $S_{\mathrm{PA}-\mathrm{MAX}}$ and the corresponding frequency of the measuring signal. The reference atmosphere was synthetic air in all cases.

\begin{tabular}{cccc}
\hline & Dc-Parameter & Ac-Parameter \\
\hline Analyte & $S_{\mathrm{DC}}$ & $S_{A C 40 \mathrm{~Hz}}$ & $S_{\text {PA-MAX }}[$ deg] at frequency [Hz] \\
$\mathrm{EtOH}(100 \mathrm{ppm})$ & 3.6 & 1.5 & 8.3 at $6 \times 10^{4} \mathrm{~Hz}$ \\
$\mathrm{EtOH}(100 \mathrm{ppm})+\mathrm{H}_{2} \mathrm{O}(100 \mathrm{ppm})$ & 2.9 & 1.5 & 8.5 at $6 \times 10^{4} \mathrm{~Hz}$ \\
$\mathrm{MeCHO}(100 \mathrm{ppm})$ & 1.5 & 2.2 & 12.5 at $2 \times 10^{5} \mathrm{~Hz}$ \\
$\mathrm{MeCHO}(100 \mathrm{ppm})+\mathrm{H}_{2} \mathrm{O}(100 \mathrm{ppm})$ & 1.3 & 2.6 & 15.5 at $2 \times 10^{5} \mathrm{~Hz}$ \\
\hline
\end{tabular}

The observation (i) is "trivial", as $\mathrm{ZnO}$ has been many times reported to exhibit n-type conductivity. The observations (ii), (iii) and (v) are apparently connected with the amount of MeCHO and amorphous carbon on the surface of ZnO NRs. As shown from the NAP-XPS measurements, the MeCHO molecules are formed as a result of the EtOH dehydrogenation and obviously undergo further decomposition. The NAP-XPS spectra confirm that the amount of amorphous carbon and $\mathrm{CH}_{\mathrm{x}}$ species on the $\mathrm{ZnO}$ surface gradually increases during the measurement. It also shows that this increase is significantly higher in the case of $\mathrm{MeCHO}$. As a result, we can formulate the following hypothesis: When detecting $\mathrm{EtOH}$ or $\mathrm{EtOH} / \mathrm{H}_{2} \mathrm{O}$, the surface of $\mathrm{ZnO}$ is only slightly decorated with amorphous carbon, oxygen species chemisorbed on the $\mathrm{ZnO}$ surface react with hydrogen atoms from $\mathrm{EtOH}$, ethoxy and $\mathrm{MeCHO}$ dehydrogenations and the sensor response is primarily determined by the exchange of electrons between chemisorbed oxygen and zinc oxide nanorod. Thus, the drift component of the current is affected, which results in a higher response when measuring in dc-mode. In this case, the concentration of produced $\mathrm{MeCHO}$ molecules probably remains below some critical amount, as it has enough time to desorb from the surface and only a very slow accumulation of the surface carbon contamination takes place. On the other hand, when detecting $\mathrm{MeCHO}$, the amount of the carbon species on $\mathrm{ZnO}$ surface is higher and the concentration of the active sites for oxygen species chemisorption is smaller. Instead, organic molecules containing dipoles are present: acetaldehyde and intermediates of the acetaldehyde oxidation. Consequently, the displacement component of the current is affected, which implies a higher response of the sensor in ac-mode. Finally, a certain decrease in the dc-response magnitude stems from the gradually increasing surface contamination.

Our results concerning the detection of $\mathrm{EtOH}$ and $\mathrm{MeCHO}$ can be compared to observations published in [46]. In that study, the nanoparticles of $\mathrm{ZnO}$ were synthesized by a hydrothermal process from zinc hydroxide and trisodium citrate, i.e., the preparation method was similar. The dc-sensitivity $S_{\mathrm{DC}}$ achieved for $100 \mathrm{ppm}$ of ethanol at $300^{\circ} \mathrm{C}$ was 7.5 and 5.0 to $100 \mathrm{ppm}$ of MeCHO. The magnitude of dc-responses was higher than that of our sensors $\left(S_{\mathrm{DC}}=3.6\right.$ to $100 \mathrm{ppm}$ of EtOH at $327^{\circ} \mathrm{C}$ and $S_{\mathrm{DC}}=1.5$ to $100 \mathrm{ppm}$ of $\mathrm{MeCHO}$ at $327^{\circ} \mathrm{C}$ - see Table 1), but the trend was the same. In both cases, the dc-responses 
to $\mathrm{EtOH}$ were greater than the responses to $\mathrm{MeCHO}$. It is notable that the authors explain the response of $\mathrm{ZnO}$ to $\mathrm{EtOH}$ and $\mathrm{MeCHO}$ only by their interaction with chemisorbed oxygen species, resulting in the total oxidation of these analytes to $\mathrm{CO}_{2}$ and $\mathrm{H}_{2} \mathrm{O}$. However, they neither carriedac-measurement nor analyzed surface deposits on the $\mathrm{ZnO}$ nanoparticles. Contrary to their conclusion, we proved that surface species play an important role in influencing the detection mechanism.

The influence of water on the sensitivity of $\mathrm{ZnO}$ nanoparticles to ethanol at a high temperature was published in [47]. It was shown that the response to $300 \mathrm{ppm}$ ethanol (measured at $400{ }^{\circ} \mathrm{C}$ ) was slightly decreased (by 3-14\%) in the atmosphere containing 56\% relative humidity, which is consistent with our observation (iv). The low influence of water on the sensitivity of ZnO-based chemiresistors at high temperatures is most probably related to the rapid desorption of water molecules from $\mathrm{ZnO}$ surface. It was shown that the adsorption probability of $0.1 \mathrm{ML}$ of water on $\mathrm{ZnO}$ surface at $330^{\circ} \mathrm{C}$ approaches zero [48], which means a weak blocking of adsorption sites for oxygen and ethanol molecules.

\section{Conclusions}

This work presents the results of the in situ NAP-XPS investigation of the EtOH- and $\mathrm{MeCHO}-$ sensing properties of $\mathrm{ZnO}$ nanorods at high temperature. We demonstrated that the $\mathrm{EtOH}$-sensing mechanism at high temperature $\left(327^{\circ} \mathrm{C}\right)$ is based on the dehydrogenation of $\mathrm{EtOH}$ molecules, leading to ethoxy and $\mathrm{MeCHO}$, where the detached hydrogens interact with the chemisorbed oxygen, causing a sensor response. It was also shown that $\mathrm{MeCHO}$ further decomposes on the surface producing amorphous carbon and various $\mathrm{CH}_{\mathrm{x}}$ species, which seemed to be responsible for the decay in dc-sensor detection performance. When detecting $\mathrm{EtOH}$, the concentration of generated $\mathrm{MeCHO}$ molecules remained relatively low, so that it had enough time do desorb or to completely oxidize causing a relatively slow accumulation of the surface carbon contamination on the surface of $\mathrm{ZnO}$, so the chemisorbed oxygen species could react with the detached hydrogen atoms, preserving the sensitivity. On the other hand, in the case of MeCHO-sensing, the carbon contamination on the surface is substantially higher and partially blocks the oxygen chemisorption on it. This phenomenon leads to the decrease in the dc-response magnitude and affection of the displacement component of the current, causing higher sensor responses in ac-mode.

Supplementary Materials: The following are available online at http://www.mdpi.com/1424-8220/20/19/5602/s1, Figure S1: AFM image of the ZnO seed layer on silicon wafer by PLD, Figure S2: Photo of measurement apparatus used for the sensor response measurements in AC mode, Figures S3 and S4: Supplementary NAP-XPS spectra.

Author Contributions: Conceptualization, M.V. (Mykhailo Vorokhta) and M.V. (Martin Vrňata); methodology, M.V. (Mykhailo Vorokhta); software, L.P., D.T., M.H.; validation, P.F. and R.Y.; formal analysis, P.F.; investigation, L.P., D.T., M.H., I.K., J.N., R.Y. and J.G.; resources, I.M. and M.V. (Martin Vrňata); data curation, P.F.; writing - original draft preparation, M.V. (Mykhailo Vorokhta) and M.V. (Martin Vrňata); writing-review and editing, L.P., D.T., M.H., I.K., P.F., R.Y., J.G., I.M.; visualization, L.P. and M.H.; supervision, I.M.; project administration, M.V. (Mykhailo Vorokhta); funding acquisition, I.M and M.V. (Martin Vrňata). All authors have read and agreed to the published version of the manuscript.

Funding: This research was funded by the Czech Science Foundation, grant number 19-02804S.

Acknowledgments: We would like to thank the Central European Research Infrastructure Consortium (CERIC) for access to experimental facilities. This work was supported by the grant of Specific university research-grant No. A2_FCHI_2020_013.

Conflicts of Interest: The authors declare no conflict of interest.

\section{References}

1. Norton, D.P.; Heo, Y.W.; Ivill, M.P.; Ip, K.; Pearton, S.J.; Chisholm, M.F.; Steiner, T. ZnO: Growth, doping and processing. Mater. Today 2008, 7, 34-40. [CrossRef]

2. Kuld, S.; Thorhauge, M.; Falsig, H.; Elkjær, C.F.; Helveg, S.; Chorkendorff, I.; Sehested, J. Quantifying the promotion of $\mathrm{Cu}$ catalysts by $\mathrm{ZnO}$ for methanol synthesis. Science 2016, 352, 969-974. [CrossRef] [PubMed] 
3. Leschkies, K.S.; Divakar, R.; Basu, J.; Enache-Pommer, E.; Boercker, J.E.; Carter, C.B.; Kortshagen, U.R.; Norris, D.J.; Aydil, E.S. Photosensitization of $\mathrm{ZnO}$ nanowires with CdSe quantum dots for photovoltaic devices. Nano Lett. 2007, 7, 1793-1798. [CrossRef]

4. Vittal, R.; Ho, K.C. Zinc oxide based dye-sensitized solar cells: A review. Renew. Sustain. Energy Rev. 2017, 70, 920-935. [CrossRef]

5. Guo, J.; Zhang, J.; Zhu, M.; Ju, D.; Xu, H.; Cao, B. High-performance gas sensor based on ZnO nanowires functionalized by Au nanoparticles. Sens. Actuators B Chem. 2014, 199, 339-345. [CrossRef]

6. Kumar, R.; Al-Dossary, O.; Kumar, G.; Umar, A. Zinc oxide nanostructures for NO2 gas-sensor applications: A review. NanoMicro Lett. 2015, 7, 97-120. [CrossRef]

7. Maziarz, W.; Rydosz, A.; Pisarkiewicz, T.; Domański, K.; Grabiec, P. Gas-sensitive properties of Zno nanorods/nanowires obtained by electrodeposition and electrospinning methods. Procedia Eng. 2012, 47, 841-844. [CrossRef]

8. Batzill, M.; Diebold, U. The surface and materials science of tin oxide. Prog. Surf. Sci. 2005, 79, 47-154. [CrossRef]

9. Seiyama, T.; Kato, A.; Fujiishi, K.; Nagatani, M. A New Detector for Gaseous Components Using Semiconductive Thin Films. Anal. Chem. 1962, 34, 1502-1503. [CrossRef]

10. Suzuki, T.T.; Ohgaki, T.; Adachi, Y.; Sakaguchi, I.; Nakamura, M.; Ohashi, H.; Aimi, A.; Fujimoto, K. Ethanol Gas Sensing by a Zn-Terminated ZnO(0001) Bulk Single- Crystalline Substrate. ACS Omega 2020. [CrossRef] [PubMed]

11. Tharsika, T.; Thanihaichelvan, M.; Haseeb, A.S.M.A.; Akbar, S.A. Highly sensitive and selective ethanol sensor based on zno nanorod on $\mathrm{SnO} 2$ thin film fabricated by spray pyrolysis. Front. Mater. 2019, 6, 1-9. [CrossRef]

12. Kaur, N.; Singh, M.; Comini, E. One-Dimensional Nanostructured Oxide Chemoresistive Sensors. Langmuir 2020, 36, 6326-6344. [CrossRef] [PubMed]

13. Yamazoe, N. New approaches for improving semiconductor gas sensors. Sens. Actuators B Chem. 1991, 5, 7-19. [CrossRef]

14. Gurlo, A. Interplay between $\mathrm{O} 2$ and $\mathrm{SnO} 2$ : Oxygen ionosorption and spectroscopic evidence for adsorbed oxygen. ChemPhysChem 2006, 7, 2041-2052. [CrossRef] [PubMed]

15. Abokifa, A.A.; Haddad, K.; Fortner, J.; Lo, C.S.; Biswas, P. Sensing mechanism of ethanol and acetone at room temperature by $\mathrm{SnO} 2$ nano-columns synthesized by aerosol routes: Theoretical calculations compared to experimental results. J. Mater. Chem. A 2018, 6, 2053-2066. [CrossRef]

16. Shankar, P.; Rayappan, J.B.B. Room temperature ethanol sensing properties of ZnO nanorods prepared using an electrospinning technique. J. Mater. Chem. C 2017, 5, 10869-10880. [CrossRef]

17. Chen, Y.; Zhu, C.L.; Xiao, G. Reduced-temperature ethanol sensing characteristics of flower-like ZnO nanorods synthesized by a sonochemical method. Nanotechnology 2006, 17, 4537-4541. [CrossRef]

18. Bhati, V.S.; Hojamberdiev, M.; Kumar, M. Enhanced sensing performance of ZnO nanostructures-based gas sensors: A review. Energy Rep. 2020, 6, 46-62. [CrossRef]

19. Leonardi, S.G. Two-dimensional zinc oxide nanostructures for gas sensor applications. Chemosensors 2017, 5, 17. [CrossRef]

20. Zhu, L.; Zeng, W. Room-temperature gas sensing of ZnO-based gas sensor: A review. Sens. Actuators A Phys. 2017, 267, 242-261. [CrossRef]

21. Wang, L.; Kang, Y.; Liu, X.; Zhang, S.; Huang, W.; Wang, S. ZnO nanorod gas sensor for ethanol detection. Sens. Actuators B Chem. 2012, 162, 237-243. [CrossRef]

22. Roy, S.; Banerjee, N.; Sarkar, C.K.; Bhattacharyya, P. Development of an ethanol sensor based on CBD grown ZnO nanorods. Solid State Electron. 2013, 87, 43-50. [CrossRef]

23. Mani, G.K.; Rayappan, J.B.B. ZnO nanoarchitectures: Ultrahigh sensitive room temperature acetaldehyde sensor. Sens. Actuators B Chem. 2016, 223, 343-351. [CrossRef]

24. Nowicki, M. A modified impedance-frequency converter for inexpensive inductive and resistive sensor applications. Sensors 2019, 19, 121. [CrossRef] [PubMed] 
25. Bobkov, A.; Varezhnikov, A.; Plugin, I.; Fedorov, F.S.; Trouillet, V.; Geckle, U.; Sommer, M.; Goffman, V.; Moshnikov, V.; Sysoev, V. The multisensor array based on grown-on-chip zinc oxide nanorod network for selective discrimination of alcohol vapors at sub-ppm range. Sensors 2019, 19, 4265. [CrossRef]

26. Gurlo, A.; Riedel, R. In situ and operando spectroscopy for assessing mechanisms of gas sensing. Angew. Chem. Int. Ed. 2007, 46, 3826-3848. [CrossRef] [PubMed]

27. Hongsith, N.; Wongrat, E.; Kerdcharoen, T.; Choopun, S. Sensor response formula for sensor based on $\mathrm{ZnO}$ nanostructures. Sens. Actuators B Chem. 2010, 144, 67-72. [CrossRef]

28. Geunjae, K.; Kijung, Y. Adsorption and reaction of ethanol on $\mathrm{ZnO}$ nanowires. J. Phys. Chem. C 2008, 112, 3036-3041.

29. Xu, J.; Han, J.; Zhang, Y.; Sun, Y.; Xie, B. Studies on alcohol sensing mechanism of ZnO based gas sensors. Sens. Actuators B Chem. 2008, 132, 334-339. [CrossRef]

30. Baikie, I.D.; Grain, A.; Sutherland, J.; Law, J. Near ambient pressure photoemission spectroscopy of metal and semiconductor surfaces. Phys. Status Solidi 2015, 12, 259-262. [CrossRef]

31. Prosvirin, I.P.; Bukhtiyarov, A.V.; Bluhm, H.; Bukhtiyarov, V.I. Application of near ambient pressure gas-phase $\mathrm{X}$-ray photoelectron spectroscopy to the investigation of catalytic properties of copper in methanol oxidation. Appl. Surf. Sci. 2016, 363, 303-309. [CrossRef]

32. Wolfbeisser, A.; Kovács, G.; Kozlov, S.M.; Föttinger, K.; Bernardi, J.; Klötzer, B.; Neyman, K.M.; Rupprechter, G. Surface composition changes of $\mathrm{CuNi}-\mathrm{ZrO} 2$ during methane decomposition: An operando NAP-XPS and density functional study. Catal. Today 2017, 283, 134-143. [CrossRef]

33. Vorokhta, M.; Khalakhan, I.; Vondráček, M.; Tomeček, D.; Vorokhta, M.; Marešová, E.; Nováková, J.; Vlček, J.; Fitl, P.; Novotný, M.; et al. Investigation of gas sensing mechanism of $\mathrm{SnO} 2$ based chemiresistor using near ambient pressure XPS. Surf. Sci. 2018, 687, 284-290. [CrossRef]

34. Hozák, P.; Vorokhta, M.; Khalakhan, I.; Jarkovská, K.; Cibulková, J.; Fitl, P.; Vlček, J.; Fara, J.; Tomeček, D.; Novotný, M.; et al. New Insight into the Gas-Sensing Properties of CuOx Nanowires by Near-Ambient Pressure XPS. J. Phys. Chem. C 2019, 123, 29739-29749. [CrossRef]

35. Yatskiv, R.; Tiagulskyi, S.; Grym, J.; Vaniš, J.; Bašinová, N.; Horak, P.; Torrisi, A.; Ceccio, G.; Vacik, J.; Vrňata, M. Optical and electrical characterization of $\mathrm{CuO} / \mathrm{ZnO}$ heterojunctions. Thin Solid Films 2020, 693, 137656. [CrossRef]

36. Tomecek, D.; Hruska, M.; Fitl, P.; Vlcek, J.; Maresova, E.; Havlova, S.; Patrone, L.; Vrnata, M. Phthalocyanine Photoregeneration for Low Power Consumption Chemiresistors. ACS Sens. 2018, 3, 2558-2565. [CrossRef]

37. Myslík, V.; Vysloužil, F.; Vrňata, M.; Rozehnal, Z.; Jelíinek, M.; Fryček, R.; Kovanda, M. Phase ac-sensitivity of oxidic and acetylacetonic gas sensors. Sens. Actuators B Chem. 2003, 89, 205-211. [CrossRef]

38. Fitl, P.; Vrnata, M.; Kopecky, D.; Vlcek, J.; Skodova, J.; Bulir, J.; Novotny, M.; Pokorny, P. Laser deposition of sulfonated phthalocyanines for gas sensors. Appl. Surf. Sci. 2014, 302, 37-41. [CrossRef]

39. Mudiyanselage, K.; Burrell, A.K.; Senanayake, S.D.; Idriss, H. XPS and NEXAFS study of the reactions of acetic acid and acetaldehyde over UO2(100) thin film. Surf. Sci. 2019, 680, 107-112. [CrossRef]

40. Jacobs, G.; Keogh, R.A.; Davis, B.H. Steam reforming of ethanol over Pt/ceria with co-fed hydrogen. J. Catal. 2007, 245, 326-337. [CrossRef]

41. Vohs, J.M.; Barteau, M.A. Formation of Stable Alkyl and Carboxylate Intermediates in the Reactions of Aldehydes on the $\mathrm{ZnO}(0001)$ Surface. Langmuir 1989, 5, 965-972. [CrossRef]

42. Singh, M.; Kaur, N.; Drera, G.; Casotto, A.; Ermenegildo, L.S.; Comini, E. SAM Functionalized ZnO Nanowires for Selective Acetone Detection: Optimized Surface Specific Interaction Using APTMS and GLYMO Monolayers. Adv. Funct. Mater. 2020, 2003217, 1-12. [CrossRef]

43. Zuo, J.; Erbe, A. Optical and electronic properties of native zinc oxide films on polycrystalline Zn. Phys. Chem. Chem. Phys. 2010, 12, 11467-11476. [CrossRef] [PubMed]

44. Wang, C.; Yin, L.; Zhang, L.; Xiang, D.; Gao, R. Metal oxide gas sensors: Sensitivity and influencing factors. Sensors 2010, 10, 2088-2106. [CrossRef] [PubMed]

45. Zimmermann, P.; Sobotík, P.; Kocán, P.; Ošt'Ádal, I.; Vorokhta, M.; Acres, R.G.; Matolín, V. Adsorption of ethylene on $\mathrm{Sn}$ and in terminated $\mathrm{Si}(001)$ surface studied by photoelectron spectroscopy and scanning tunneling microscopy. J. Chem. Phys. 2016, 145, 094701. [CrossRef]

46. Rai, P.; Yu, Y.T. Citrate-assisted hydrothermal synthesis of single crystalline ZnO nanoparticles for gas sensor application. Sens. Actuators B Chem. 2012, 173, 58-65. [CrossRef] 
47. Saboor, F.H.; Khodadadi, A.A.; Mortazavi, Y.; Asgari, M. Microemulsion synthesized silica/ZnO stable core/shell sensors highly selective to ethanol with minimum sensitivity to humidity. Sens. Actuators B Chem. 2017, 238, 1070-1083. [CrossRef]

48. Kunat, M.; Girol, S.G.; Burghaus, U.; Wöll, C. The Interaction of Water with the Oxygen-Terminated, Polar Surface of ZnO. J. Phys. Chem. B 2003, 107, 14350-14356. [CrossRef] 